\title{
'n Deskriptiewe ondersoek na Sheila Cussons se poësievertalings aan die hand van Lefevere se sewe strategieë
}

\author{
Marius Swart \\ Departement Afrikaans en Nederlands, Universiteit Stellenbosch, Suid-Afrika \\ E-pos: mariusswart@sun.ac.za
}

\section{Opsomming}

Sheila Cussons word as een van die grootste Afrikaanse digters beskou. Melding van belangrike temas in haar oeuvre word algemeen in bestaande navorsing gemaak, byvoorbeeld oor vuur (De Villiers 1982), die visuele (Scholtz 1991), religieuse intertekste (Matthee 1984, Engelbrecht 2012), die bonatuurlike, goddelike of metafisiese (De Villiers 1984; Gilfillan 1984), asook die Katolieke en die mistieke in haar werk (Van Vuuren 1989), en die belang van metapoësie (Janse van Rensburg 1995). Kannemeyer (2005:453-459) verwys veral na Cussons se tegniese bedrewenheid en lig ook die "verwagtende uitsien na eenwording en die versmelting met God" (2005:457) as 'n sentrale motief in haar werk uit. Dit is egter nie so algemeen bekend of so omvattend nagevors dat Cussons ook in die 1980's 'n bundel vertalings van haar eie poësie onder die titel Poems: a selection (1985) by Tafelberg gepubliseer het nie. Dié bundel bestaan uit seleksies uit haar bundels vanaf Plektrum (1970) tot by Membraan (1984) (Cussons 1985). In hierdie artikel, wat deel uitmaak van 'n meer omvattende ondersoek oor poësievertaling, word gepoog om deur 'n vergelykende lees van die Afrikaanse en Engelse gedigte in die bundel te bepaal of daar by Cussons 'n definieerbare "tipiese" vertaalstrategie of -strategieë afgelees kan word teen die agtergrond van Lefevere (1975) se beskrywing van sewe strategieë vir die vertaling van poësie. Daar word bevind dat Cussons se vertalings met sommige van Lefevere se strategieë ooreenstem, maar van ander geen blyke gee nie. Verder word daar in sekere vertalings strategieë aangewend wat nie onder Lefevere se raamwerk verklaar of ingedeel kan word nie, en in heelparty gevalle word daar op die oog af gewoon idiosinkraties vertaal. Ten slotte word aanvullings by Lefevere se model voorgestel vir die ontwikkeling van 'n vollediger raamwerk vir die bestudering van vertaalde Afrikaanse poësie.

Sleutelwoorde: Cussons, poësievertaling, Lefevere, vertaalstrategieë, literêre vertaling

\section{A descriptive investigation into the poetry translations of Sheila Cussons using Lefevere's seven strategies}

\section{Extended Abstract}

Sheila Cussons is generally seen as one of the great Afrikaans poets. Important subjects in her work include fire (De Villiers 1982), the visual (Scholtz 1991), religious intertexts (Matthee 1984; Engelbrecht 2012), the supernatural and metaphysical (De Villiers 1984, Gilfillan 1984) as well as Catholicism and mysticism (Van Vuuren 1989), and the importance of meta-poetry 
(Janse van Rensburg 1995). Kannemeyer (2005:453-459) notes her technical prowess and points out the expectation of becoming one with God as a central theme in her work.

Cussons is also known for her translations of Borges' stories into Afrikaans under the title of Die vorm van die swaard en ander verhale (1981). However, it is not as well known or well researched that she also published a volume of translated poems from her own work in the 1980s, entitled Poems: a selection (1985). This volume contains selections from her poetry from the titles Plektrum (1970) to Membraan (1984) (Cussons 1985). A descriptive investigation into the translations contained in Poems: a selection is offered in this article.

According to Connoly, approaches to poetry translation often seem anecdotal and subjective (2001:170). This view is echoed by statements such as those likening poetry translation to playing a piano sonata on a trombone (Kelly and Zetzsche 2012:106), or descriptions of reading a translation as being like kissing through a veil or looking at the back of a tapissery (Bialik in Feinstein 2005:xvii). The challenging nature of poetry translation is also strongly implied by oft-cited quotes like that of Robert Frost, describing poetry as that which gets lost in translation (Bassnett 1998:57). Whether implicitly or directly put, the first, if not central question in numerous works on poetry translation seems to be whether poetry can be translated at all (Boase-Beier 2009:194).

Nonetheless, poetry translation occupies a central position in the history of translation studies. Steiner's seminal study After Babel (1975) essentially discusses the problems of poetry translation. Through the course of the $20^{\text {th }}$ century a number of important works on poetry translation have also been published - examples include Raffel's The art of translating poetry (1988), Robinson's Poetry and translation. The art of the impossible (2010), Levy's Umeni prekladu (1963), published in English recently as The art of translation (2011), and Poetry translation as expert action (Jones 2011).

For the purposes of this investigation, a component of a more comprehensive study of the realities and potentialities of Afrikaans poetry in English translation, it is assumed that poetry is indeed translatable, that poetry translation, per definition, brings about something that would not otherwise have existed, that poetry translation requires certain expertise, and that the study of translated poetry could yield valuable insights for translation studies and translator training.

Therefore the investigation starts with one of the first sources attempting a structured discussion of possible strategies for poetry translation: Translating poetry - Seven strategies and a blueprint (Lefevere 1975). Fochi (2011) describes this text as one of the formative sources in linking methodological frameworks with translation criticism. She concludes that despite the relative age of the book, there is still much room for case studies testing its insights in different languages (Fochi 2011).

This article attempts such a case study by considering translations by Sheila Cussons of her own poetry. The investigation is done by means of a descriptive and product-orientated reading against the backdrop of Lefevere's seven strategies for poetry translation. The purpose of this reading, comprising a comparison of the Afrikaans and English poems in Poems: a selection in the context of Lefevere's theory, is to determine whether a "typical" translation strategy or strategies can be identified in Cussons' translations. Selections are made to illustrate Lefevere's 
points as needed, rather than providing line-by-line discussions of poems. Methodological shortcomings are identified and suggestions for improvement and further study are made.

Lefevere describes seven possible strategies for poetry translation. Firstly, phonemic translation (1975:19), in which a poem sacrifices some semantic meaning for the sake of sound retention. Cussons does not seem to make use of this kind of translation. Secondly, Lefevere refers to literal translation, where the sentence structure and meaning are put in a secondary position for the sake of retaining literal semantic equivalence (1975:27). This is nothing new in translation studies: Nabokov and many other scholars have held the opinion that a literal translation with accompanying notes is somehow more faithful or accurate, and therefore the preferred form (see for example Nabokov 1955). Cussons does not make use of this strategy either, although there are a few cases where the English translation does seem somewhat unidiomatic. Thirdly, Lefevere refers to metrical translation, where the metre is retained in translation (1975:37). This can cause difficulty in understanding the translation. Unsurprisingly, Cussons does not make use of this strategy at all. In fact, she often sacrifices a metrical attribute for the sake of semantic transfer. Similarly, she does not make use of (often somewhat forced) rhyming translations, Lefevere's fourth strategy (1975:60), either. The fifth strategy, the free verse form, which can easily digress into merely "arbitrarily cut-up prose" (1975:61) is used rather extensively by Cussons, although without losing poetic structure as warned by Lefevere. She often seems to reimagine certain lines, sometimes adding or deleting others, but these changes are still relatively minor (never adding or deleting more than one line) and not common at all (doing it only in 11 out of 37 poems). Lefevere's last two strategies, the prose translation (1975:42-43) and the version/imitation (1975:76) are not used exactly as described in this volume.

It would seem that Cussons' translations do not show signs of all the possible strategies listed by Lefevere. Nonetheless, her translations also show certain strategies or mannerisms that cannot be classified using Lefevere's model. The apostrophe is never used to indicate possessive forms - instead, the preposition "of" is used. Words containing religious or divine references are translated in a fashion pointing towards idiosyncrasy on the level of capitalisation. The format of four titles is adjusted and in a number of cases, meaning is explicated in the translation. Additionally, words related to fire and light, an important theme in the poet's work, are translated in a fashion indicating a similar idiosyncratic strategy.

It is worth noting that Lefevere does not work specifically in the context of self-translation in his 1975 book. Furthermore, the source and target cultures in his case (translations from Latin of poem 64 by Catullus by various translators) are probably much further removed than in the case of the Cussons poems (which, despite being English translations, were published by a South African publisher, with the Afrikaans source texts in the same volume). Nonetheless, this example of Lefevere's work in systematising the study of poetry translation, as described above, provides a useful framework.

In conclusion, it seems as though Lefevere's strategies typically describe more significant changes than those apparent in Cussons' translations, with the possible exception of "Christ of the burnt men" (Cussons 1985:32-33), which was cut and changed significantly. All of the other translations bear a very strong resemblance to their Afrikaans source texts on the levels of form, content and meaning. One could assume that it is rather more simple for the translator to follow the road mapped out by the poet, as Lefevere puts it (1975:103), when these two roles are taken up by the same person. Lefevere's strategies, however, do not offer a sufficient framework for 
fully describing these translations. In descriptive terms, one is left wanting, especially considering the description of the theoretical text as a "blueprint".

Although Lefevere is seen as a pioneer of the more systematic description of poetry translation, there are certain shortcomings in his classification which become apparent in a practical comparison of the English translations to the Afrikaans source texts. Certain translation strategies, such as the free verse form and the interpretation (versions rather than imitations, as shown above), are described and explained well. Other tendencies, such as capitalisation, microtextual changes and inconsistency, cannot be as readily classified in his framework.

Of course, Lefevere himself expresses doubts about the use of a purely linguistic approach to translation analysis, since this could cause the investigator to get stuck on linguistic aspects of the given text only, and therefore also only the linguistic aspects of the translation process (1975:3).

In my view, however, a more language-orientated approach in combination with Lefevere's initial strategies could be of greater use than either of the two on their own in the descriptive study of poetry translation from Afrikaans into English. This hypothesis is expanded and tested in a forthcoming publication.

Keywords: Cussons, poetry translation, Lefevere, literary translation, translation strategies

\section{Inleiding}

Volgens Connolly is die perspektiewe waaruit poësievertaling bestudeer word, helaas meestal anekdoties en subjektief (2001:170). Daar is in die vertaalkunde weliswaar heelparty aanhalings om hierdie standpunt te ondersteun, byvoorbeeld Nataly Kelly wat beweer dat poësievertaling is soos om 'n klaviersonate op 'n tromboon te probeer speel (Kelly en Zetzsche 2012:106) of die bekende Hebreeuse digter Hayim Nachman Bialik se mening dat die lees van 'n vertaling kan wees soos om deur 'n sluier te soen of na die agterkant van 'n tapisserie te kyk (Feinstein 2005:xvii). Die uitdagende aard van poësievertaling word ook geïmpliseer deur byvoorbeeld Robert Frost se veelaangehaalde stelling dat poësie juis dit is wat verlore gaan in vertaling (Bassnett 1998:57), of deur die siening dat die sentrale vraag by poësievertaling, hetsy implisiet of eksplisiet, is óf poësie hoegenaamd vertaal kan word (Boase-Beier 2009:194).

Poësievertaling staan egter regdeur die geskiedenis van die vertaalkunde sentraal. Steiner se seminale After Babel (1975) behandel byvoorbeeld in essensie die problematiek van poësievertaling. Daar verskyn ook deur die loop van die 20 ste eeu etlike belangrike selfstandige werke wat implisiet of eksplisiet oor poësievertaling handel - enkele voorbeelde in laasgenoemde verband is Raffel se The art of translating poetry (1988), Robinson se Poetry \& translation. The art of the impossible (2010), Levý se beskouing van poësievertaling as kunsvorm in die vorm van die Hongaarse Umení prekladu (1963), onlangs in Engels gepubliseer as The art of translation (2011), en Jones se Poetry translating as expert action (2011).

Ook oor wat presies poësievertaling behels, is daar velerlei uitsprake gemaak wat nie binne die bestek van 'n enkele artikel deurgewerk kan word nie. Robinson (2010:46) noem byvoorbeeld 
dat daar in die diskoers oor poësievertaling sprake is van twee standpunte oor hoe poësievertaling "getrou" kan wees: deur óf die vorm te behou ten koste van die betekenis, óf die betekenis te behou ten koste van die vorm. Kenesei, daarenteen, beskryf poësievertaling meer genuanseerd as die vasstelling en oordrag van sowel mikro- as makro-metafories uitgedrukte inhoud (2010:42). In 'n genre waar sulke wydlopende kompleksiteite geld, kan die nadere bestudering van voorbeelde daarvan nuttige antwoorde oor vertaalkwessies as sodanig bied.

Vir die doeleindes van hierdie ondersoek, wat 'n onderdeel van 'n groter ondersoek na die vertaalbaarheid en vertaalwerklikhede by Afrikaanse poësie vorm, word van die voorveronderstellings uitgegaan dat poësie wel vertaalbaar is, dat poësievertaling per definisie ' $n$ aktiwiteit is wat meer oplewer as wat dit voorafgaan, dat poësievertaling bepaalde kundigheid vereis, en dat daar uit die bestudering van poësievertalings belangrike en relevante insigte onttrek kan word vir die vertaalkunde en vertaalopleiding. Om hierdie rede word in hierdie ondersoek begin by een van die eerste bronne waarin gepoog is om die strategieë van poësievertaling uiteen te sit: Lefevere se Translating poetry - Seven strategies and a blueprint (1975). Volgens Fochi (2011) is hierdie werk van Lefevere een van die basisbronne wat die metodologiese raamwerk met die vertaalkritiek begin verbind het en is daar, ten spyte van die feit dat die bron relatief oud is, nog heelwat ruimte vir gevallestudies waar die insigte daarin getoets word aan voorbeelde in verskillende tale.

In hierdie artikel word so 'n gevallestudie uitgevoer deur ondersoek in te stel na vertalings wat Sheila Cussons van haar eie poësie gemaak het, en wel vanuit 'n bestudering van die vertaalproduk en nie die vertaalproses nie, aan die hand van Lefevere se sewe strategieë vir die vertaling van poësie. Deur middel van 'n vergelykende lees van die Afrikaanse en Engelse gedigte in die bundel, binne die raamwerk van Lefevere (1975) se uitleg van sewe vertaalstrategieë vir die vertaling van poësie, word gepoog om te bepaal of daar by Cussons 'n definieerbare "tipiese" vertaalstrategie of -strategieë afgelees kan word uit die moontlikhede wat Lefevere se uiteensetting voorstel. Die vertalings word gelyklopend gelees en seleksies word gemaak om blyke van Lefevere se strategieë oor die bundel heen aan te toon eerder as om enkele gedigte reël vir reël te analiseer. Laastens word tekortkominge uitgewys en voorstelle vir verdere ondersoeke aangevoer.

\section{Sheila Cussons as digter en vertaler}

Sheila Cussons word as een van die grootste Afrikaanse digters beskou. Haar bundels sluit in Plektrum (1970), Die swart kombuis (1978), Verf en vlam (1978), Die skitterende wond (1979), Die sagte sprong (1979), Die somerjood (1980), Die woedende brood (1981), Verwikkelde lyn (1983), Membraan (1984), Die heilige modder (1988) en Die knetterende woord (1990), asook drie publikasies van 'n keur uit haar werk met die titels Omtoorvuur (1982), 'n Engel deur my kop (1997) en Die asem wat ekstase is (2000) (Gilfillan 1984:151, Kannemeyer 2005:453-459). Haar Versamelde gedigte verskyn in 2006, waarby vrae ook ontstaan oor haar ongepubliseerde werk in die dekade 1943 tot 1953 (Hambidge 2013).

Melding van belangrike temas in haar oeuvre word algemeen in bestaande navorsing gemaak, byvoorbeeld oor vuur (De Villiers 1982), die visuele (Scholtz 1991), religieuse intertekste (Matthee 1984, Engelbrecht 2012), die bonatuurlike, goddelike of metafisiese (De Villiers 1984, Gilfillan 1984), asook die Katolieke en die mistieke in haar werk (Van Vuuren 1989), en 
die belang van metapoësie (Janse van Rensburg 1995). Kannemeyer (2005:453-459) verwys veral na Cussons se tegniese bedrewenheid, reeds sedert haar debuutwerk, haar oorspronklikheid, die rykheid aan simboliek van haar poësie, haar gebruik van Bybelse motiewe, haar verbinding van "realisme en magie", asook die gebruik van "mitologiese en sprokieselemente". Kannemeyer lig eweneens die "verwagtende uitsien na eenwording en die versmelting met God" (2005:457) as 'n sentrale motief in haar werk uit. Verder is Cussons die vertaler van verhale deur Jorge Luis Borges onder die titel Die vorm van die swaard en ander verhale (1981).

Dit is egter nie so algemeen bekend of so omvattend nagevors dat Cussons ook in die 1980's 'n bundel vertalings van haar eie werk onder die titel Poems: a selection (1985) by Tafelberg gepubliseer het nie. Dié bundel bestaan uit seleksies uit haar bundels vanaf Plektrum tot by Membraan (Cussons 1985).

Die bundel bevat 37 gedigte in Afrikaans, elk met 'n Engelse vertaling. Die gedigte is gegroepeer onder die titel van die bundel waarin hulle oorspronklik verskyn het en dié bundelgroeperings is op hulle beurt chronologies geplaas. Daar is sewe gedigte elk uit Membraan en Die sagte sprong, ses gedigte elk uit Plektrum en Die swart kombuis, drie elk uit Die woedende brood en Verwikkelde lyn, twee elk uit Die skitterende wond en Somerjood, en een uit Verf en vlam (Cussons 1985).

Op die kolofon word die nege bundeltitels in chronologiese volgorde gelys met Engelse vertalings van die titels langsaan, en in die inhoudsopgawe word slegs hierdie Engelse "titels" (daar bestaan nie werklik sulke publikasies nie) gegee - Plectrum, The black kitchen, Paint and flame, The brilliant wound, The soft pounce, The Summer Jew, The furious bread, Complex line en Membrane (Cussons 1985).

\section{Lefevere se sewe strategieë vir poësievertaling}

Lefevere word beskou as 'n teoretikus wie se werk in die vertaalkunde ontwikkel het uit sy sterk bande met die sogenaamde manipulasiekool (Munday 2008:125), 'n groepering wat op sy beurt sterk bande met die polisisteemteorie en die deskriptiewe vertaalkunde, oftewel "DTS" (Descriptive Translation Studies), gehad het (Munday 2008:118-119). In later jare verskuif Lefevere se fokus veral na die rol van ideologie en patronaatverhoudinge in literêre vertaling en word hy beskou as een van die oorbruggingsdenkers in die oorgang na die sogenaamde kulturele wending in die vertaalkunde (Munday 2008:125). Sy publikasie wat in hierdie ondersoek benut word, kom reeds uit 1975, nagenoeg 'n dekade voor die publikasie van die seminale The manipulation of literature: Studies in literary translation (Hermans 1985). Reeds in 1976 is daar egter al in Leuven 'n kongres gehou wat beskou word as een van die prominente beginpunte van die manipulasieskool (Munday 2008:118), so dit is veilig om Lefevere se studie te lees as een van die eerste voorbeelde van 'n bruikbare deskriptiewe benadering tot poësievertaling. Die boek is weliswaar in drie afdelings verdeel, met die subtitels "Descriptive", "Prescriptive" en "Applied" (Lefevere 1975).

Lefevere open sy ondersoek na poësievertaling met 'n feitestelling wat maklik uit die oog verloor word deur diegene wat vertalings bestudeer: vertalings kan uit die aard van die saak slegs beoordeel word deur mense wat hulle eintlik nie regtig nodig het nie (1975:7). Op die keper beskou, is dit die waarheid - slegs die persoon wat beide tale in die betrokke 
vertaalhandeling beheers, kan werklik 'n oordeel fel oor die gehalte van die vertaling. In die geval van poësievertaling is dit egter nie bloot 'n geval van 'n leser wat 'n vertaling "nodig" het in die sin van semantiese verstaanbaarheid nie. In die geval van poësie is daar uiteraard meer aan die gang as die blote oordrag van semantiese betekenis. Reeds in 1923 stel Benjamin dit dat 'n literêre werk se essensie nie die blote oordrag van inligting is nie, maar ook die skep van 'n bepaalde poëtiese effek, iets wat 'n vertaler volgens hom boonop alleen kan bereik as die vertaler self ' $n$ digter is (1923:75). Verder is die poësie 'n genre waar die skeidslyn tussen vorm en inhoud, vir lank gesien as 'n sentrale onderskeid in die vertaalkunde (vergelyk byvoorbeeld Nabokov [1955:121] se stelling dat 'n teks vir die vertaler verdeel is in vorm en inhoud, asook Robinson se verwysing na die diskoers oor poësievertaling hierbo), vervaag of selfs verdwyn.

Lefevere se stelling is dus tegnies korrek in die opsig dat slegs 'n persoon wat 'n vertaling nie werklik benodig nie, dit kan beoordeel, maar dié stelling berus op ' $n$ implisiete aanname dat slegs persone wat 'n vertaling benodig vir semantiese verstaanbaarheid van die inhoud van die bronteks, dit werklik "nodig" het. Die vraag kan gevra word of 'n leser met 'n waardering vir die spel wat 'n digter in 'n bepaalde brontaal speel, nie ewe "nodig" het om daardie spel in 'n doeltaal mee te makk nie, en wat "nodig" in hierdie konteks in elk geval beteken. Vir die liefhebber en student van die Afrikaanse poësie kan dit tog lonend wees om te sien wat Cussons se vertalings behels, hoewel sodanige bestudering nie soseer op die vlak lê van begryplike "nodigheid" nie. Dit is ook bekend dat daar minstens twee moontlike redes is vir die vertaling van literatuur en, derhalwe, poësie: om 'n teks aan 'n nuwe gehoor bloot te stel - vergelyk in hierdie verband byvoorbeeld die Versindaba-projek om Afrikaanse poësie in Engels te laat vertaal ten einde dit wêreldwyd ten toon te stel (Malan 2013) - en om 'n groter waardering vir die oorspronklike teks te skep - vergelyk in hierdie verband byvoorbeeld resensies van boeke soos Elsa Silke se vertaling van Schoeman se Hierdie lewe (1993) as This life (2005) (Van den Berg 2006:8).

Lefevere beskryf sewe strategieë vir hoe hierdie soort vertaling, spesifiek die vertaling van poësie, gedoen kan word. Daar moet in gedagte gehou word dat Lefevere sy sewe strategieë deels opstel om juis aan te dui dat geen enkele strategie op sigself waarskynlik 'n afgeronde moontlikheid of verklaring vir vertaalbesluite is nie. Lefevere sê weliswaar self dat elk van die vertaalstrategieë wat hier onder bespreek sal word, neerkom op óf 'n uitbreiding óf 'n sametrekking van die bronteks op die vlak van morfologie, betekenis, kommunikatiewe waarde, sinsbou en/of struktuur (Lefevere 1975:95) en beskryf dan die taak van die poësievertaler soos volg: om die bronteks, wat die skrywer se interpretasie van 'n bepaalde tema is wat op verskeie maniere uitgedruk word, toeganklik te maak vir lesers wat nie hierdie variasies ken nie deur die skrywer se variasies met hulle ekwivalente in 'n ander taal, tyd, plek en tradisie te vervang.

Die oordrag van betekenis alleen is dus nie genoeg nie - dit is volgens Lefevere 'n minimumvereiste (1975:99). Die vertaler moet poog om die teks se "kommunikatiewe waarde", in elke sin en op elke vlak, oor te dra (Lefevere 1975:99). Dit sluit in kultuurgebonde elemente en struktuurgebonde elemente (Lefevere 1975:100-101), met ander woorde, elemente in tekste wat aan verskillende tye, plekke en tradisies behoort. Lefevere som dit op deur te sê die vertaler moet die tema van die bronteks interpreteer (1975:103) en wel aan die hand van die padkaart wat deur die skrywer geteken is, ten einde 'n vertaling te maak wat op die oorkoepelende vlak getrou is aan die oorspronklike, terwyl fyner detail nie 'n struikelblok word nie (ibid.). 
Op hierdie punt moet spesifiek genoem word dat Lefevere nie werk in 'n konteks van selfvertaling nie, en wel in een waar die doeltaalkultuur en die brontaalkultuur op bepaalde wyses waarskynlik verder uitmekaar is (vertalings van vers 64 van Catullus uit Latyn in Engels deur 'n paar verskillende vertalers) as wat die geval by Cussons se poësie is (wat, hoewel in Engels, deur 'n Suid-Afrikaanse uitgewery en met die Afrikaanse teks in dieselfde band uitgegee is). Daarom sal bepaalde dele van die teorie noodwendig nie as verklaring kan dien vir wat Cussons doen nie. Lefevere self maak ook immers die punt dat geen enkele strategie 'n vertaling volledig kan verklaar nie, soos hierbo genoem. Vir die doeleindes van hierdie ondersoek word egter gewoon op die praktiese vlak van Lefevere se sewe strategieë gebruik gemaak, as poging tot 'n verklaringsraamwerk vir bepaalde vertaalkeuses om te bepaal watter elemente daarvan wel nuttig is.

Voorts sal elk van Lefevere se strategieë benut word om Cussons se vertalings ondersoekend te beskryf.

\section{Deskriptiewe analise van Cussons se vertalings volgens Lefevere se strategieë ${ }^{1}$}

Die benadering wat in hierdie praktiese gedeelte gevolg word, stem ooreen met Toury se drie stappe vir die deskriptiewe bestudering van 'n vertaalde teks (soos beskryf in Toury 1995:38 en meer uitvoerig bespreek in Swart 2009). Die bronteks en vertaling word langs mekaar beskou, vergelykbare eenhede (hetsy hele gedigte, geselekteerde versreëls of enkele woorde, afhangende van die betrokke geval) word vergelyk, en veralgemenings word daaruit afgelei in 'n poging om vertaalbesluite te beskryf en afleidings oor die vertaalproses te maak. 'n Volledige bespreking van Toury se werk oor DTS en die afleiding van vertaalnorme word egter nie hier gebied nie, aangesien die fokus op Lefevere se strategieë val en daar slegs breedweg van 'n soortgelyke metode as dié wat Toury voorstel, gebruik gemaak word.

\subsection{Benutting van Lefevere se sewe strategieë}

In Lefevere se model is daar sewe strategieë wat hy vir die vertaling van poësie daarstel. Die eerste is fonemiese, oftewel klankvertaling. Dit behels dat daar primêr met klankooreenstemming gewerk word, maar ook met 'n "undercurrent of paraphrased sense" (Lefevere 1975:21). Dié soort vertaling loop gevaar om aanvanklik as onsinvers gelees te word, aangesien dit onder andere die sinsbou van die brontaal tweede stel ten gunste van getrouheid aan die klank van die vertaling (1975:19), maar kan volgens Lefevere goed werk waar eiename, klanknabootsing of etimologies verwante woorde vertaal moet word (1975:23).

In Cussons se vertaalde bundel is geen enkele voorbeeld van 'n gedig wat mank gaan aan betekenis vanweë die vooropstelling van klankbehoud nie. Die gedigte is oënskynlik semanties maklik verstaanbaar in Engels, soos in Afrikaans. Daar is wel gevalle waar 'n moontlik minder gebruiklike ekwivalent gebruik word ter wille van wat lyk na klankbehoud, byvoorbeeld in "skuins reën sketter ..." (30) wat verander in "slanted rain clattering ..." (31) of waar die Engels moontlikhede byvoeg wat nie in Afrikaans bestaan het nie, byvoorbeeld "glistening groin" (37) vir "glinsterende lies" (36) of "bowls of blue" (57) vir "komme blou" (56) en "infuriated iron" (69) vir "verwoed [e ...] yster" (68). Daar is egter ook gevalle van belangrike klankpatrone in Afrikaans, soos "Heerlike Huid" (34) wat gewoon verdwyn in Engels: "glorious skin" (35).

\footnotetext{
${ }^{1}$ Alle verwysings na gedigte in hierdie afdeling bevat die bladsynommers uit Cussons (1985).
} 
Daar is dus nie sprake daarvan dat klankbehoud by Cussons 'n deurslaggewende of algemene vertaalstrategie is in die terme waarin Lefevere dit beskryf nie, aangesien daar nie in een van die 37 vertaalde gedigte betekenis verlore gaan ter wille van klankbehoud nie.

Tweedens is daar die benadering letterlike vertaling, waar woord-vir-woordvertaling gedoen word, ten spyte van probleme wat dit op die vlak van sinsvolgorde of betekenis skep (Lefevere 1975:27). Lefevere merk op dat hierdie soort vertaling buitengewoon hoë prestige dra in die vertaalkunde, aangesien die letterlikheid van die vertaling gelykgestel word aan waardeuitdrukkings soos "akkuraat" of "presies" (ibid.) Hierdie oriëntasie is natuurlik niks nuuts nie - Nabokov maak byvoorbeeld twintig jaar voor Lefevere reeds die besonder normatiewe stelling, "[t]he clumsiest literal translation is a thousand times more useful than the prettiest paraphrase" (1955:115), en stel dit dat die vertaler alleen een opdrag het: "[To] reproduce with absolute exactitude the whole text, and nothing but the text" (1955:121, my kursivering). Nabokov wys egter self, hoewel waarskynlik onbedoeld, die probleem met hierdie soort vertaling uit, veral wanneer daar gedink word in terme van (publiseerbare) poësievertaling: "[The text] will not be able to soar and to sing[.]" (1955:121). Lefevere som die letterlike vertaling se probleem op: deur vas te klou aan 'n poging om betekenisekwivalensie te bereik, misluk die vertaler daarin om daardie bronteks as 'n literêre kunswerk in die doeltaal aan te bied (1975:37). Ook by Venuti kom in later jare 'n eggo hiervan voor wanneer hy verduidelik hoedat die dominansie van deursigtige diskoers (d.w.s. vertalings wat sogenaamd "vlot" lees) sedert die begin van die twintigste eeu met beslistheid uitgedaag is (Venuti 2008:164), hoewel hierdie uitdaging van hierdie dominansie nie werklik in vertalings neerslag gevind het (in die vorm van die soort letterlike vertaling waarna Lefevere verwys) nie (Venuti 2008:164).

In Cussons se bundel is eweneens geen voorbeelde van vertaling wat in so 'n mate woord-virwoord gedoen word dat 'n gedig moeilik verstaanbaar word nie. Daar is wel 'n paar voorbeelde waar die vertaling van enkele frases ietwat letterlik aandoen - byvoorbeeld die affodil wat beskryf word as 'n "borriegeel uitroep" (58), maar in Engels 'n "saffron-yellow exclamation" word (59), of "sê nou" (28) wat "say now" (29) word eerder as die meer idiomatiese ekwivalent "what if". Nog 'n voorbeeld is die "sonbesie-dennebos" (62) wat verander in 'n "cicada pine grove" (63). Nietemin word in 16 van die 37 gedigte minstens een maal, maar gewoonlik meer, 'n werkwoord aan die einde van die Afrikaanse reël vervang met 'n ander woordsoort in die Engelse geval om die sinsbou van Engels in ag te neem - 'n strategie wat lynreg ingaan teen wat verstaan word as letterlike vertaling ten alle koste. By Cussons is dus weinig sprake van letterlike of woord-vir-woord-vertaling as nadeel, hoewel daar heelparty gevalle is waar die vertalings uit 'n semantiese oogpunt wel bykans woord-vir-woord ooreenstem.

Die derde benadering waarna Lefevere verwys, is metriese vertaling, waar die vertaler nie so gebonde is aan die klank of betekenis van die bronteks nie, maar deur by die metrum van die bronteks te hou, steeds in staat is om op die "egtheid" van die vertaling aanspraak te maak (Lefevere 1975:37). Wat hier verklap word, is miskien iets van 'n oriëntasie tot wat poësie is dat dit die metriese aard daarvan is wat dit poësie maak, aangesien dit die behoud van die metrum is wat die vertaalde teks poëties maak? Metriese vertaling se probleme is volgens Lefevere dat dit misleidend word omdat die vertaler tegelykertyd sy interpretasie wil afdruk en die vereiste aantal jambes wil vul, terwyl dit ook die konteks buite rekening laat, soms tot op die uiterste vlak waar die vertaling onverstaanbaar word (1975:41). 
In Cussons se geval is daar regdeur die bundel geen enkele aantoonbare voorbeeld waar die metrum in die Engelse gedig vooropgestel is ten koste van 'n bepaalde ander attribuut nie. Trouens, in die meeste gevalle blyk die voorkeur vir semantiese ooreenstemming en betekenisvolledigheid te wees, heelparty keer juis ten koste van metriese gevolge, byvoorbeeld in die geval van "Sy staan reeds in die deurkosyn" (28) teenoor "she is standing already in the frame of the door" (29) of "Ek soek die dinge van hulle elke-dag,/ek soek die praat en die maklike lag" (28) teenoor "I am looking for the things of their every day,/I am looking for the talk and easy laughter" (29). 'n Laaste voorbeeld is "maar teen my tongpunt prik my huid" (18) teenoor "but against my tongue-tip my skin prickles" (19). Cussons gee duidelik nie aan metriese oorwegings voorrang bo betekenis nie.

Vierdens word prosavertalings beskryf, wat volgens Lefevere groot aansien geniet vanweë hulle elegante taalgebruik en die feit dat hulle baie akkuraat en baie na aan die bronteks kan wees omdat hulle die probleme wat met 'n vertaling in versvorm gepaard gaan, grootliks vermy (Lefevere 1975:42-43). Die probleem van hierdie strategie is egter dat prosa nie die leser se aandag na spesifieke woorde kan rig op dieselfde manier as wat dit in poësie gedoen word nie en dat ander maniere om dit te bewerkstellig, dus deur die vertaler geskep moet word, byvoorbeeld om woorde se morfologie te verander, woorde te gebruik wat semanties naby aan die brontekswoord, maar tog vreemd in die brontaal, is, etimologiese vorme te benut en leenwoorde te gebruik (Lefevere 1975:43-44). Oordrywings, eksplisiete verduideliking, toutologie en die byvoeg van bepaalde "poëtiese" elemente (alliterasie, rymwoorde, ensovoorts) in die prosavertaling is verdere strategieë wat gebruik kan word in prosavertaling (Lefevere 1975:44-46). In Cussons se bundel kom geen prosavertalings volgens hierdie definisie voor nie. Die gedigte stem deurgaans vormlik sterk ooreen met hul onderskeie brontekste.

In die vyfde plek is daar die moeilike strategie van rymende vertalings; Lefevere noem dit 'n "double bondage", omdat die vertaler deur sowel metrum as rym gebind word (1975:49). Volgens Lefevere is die moontlike opsies vir die vertaler hier die verandering van die kommunikatiewe waarde van sekere woorde, die morfologiese wysiging van die rymwoorde en die gebruik van vaste uitdrukkings (Lefevere 1975:50). Die vertaler kry egter soms nie 'n rymwoord nie en in so 'n geval word óf die versreël se betekenis óf die bou daarvan gewysig (Lefevere 1975:51-52) ter wille van die behoud van rym en metrum. Lefevere waarsku daarteen dat die nastreef van hierdie soort vertaalproduk kan lei tot onakkuraatheid, vertaalfoute, stopwoorde en uitgebreide byvoegings en parafrasering (Lefevere 1975:54-58). Lefevere som die problematiek van rymende vertalings op: "[Certain] lines in rhyming translations [...] seem to defy not only the laws of syntax, but also those of common sense" (1975:60).

In die geval van een Cussons-gedig word daar van eindryme gebruik gemaak wat verlore gaan in die Engels ter wille van, op die oog af, semantiese ooreenstemming:

Toe draai ek om en ek vind verstom ek het voor my eie deur gekom: my huis is Hare, my huis is Syne!
So I turn again and I find amazed that I have come to my own door: my house is hers, my house is His!

(Cussons 1985:28-29). 
Buiten hierdie voorbeeld is daar nie ander gevalle waar sodanige handelinge rondom rympatrone uitgevoer word nie. Dit moet uiteraard genoem word dat Cussons in die eerste plek nie in 'n rympatroon skryf in die oorgrote meerderheid gedigte in hierdie bundel nie.

Lefevere se sesde strategie staan bekend as die vryeversmodus, wat 'n moeilike balans tussen die gebruik en vermyding van metriese versreëls vereis, soos vir die bronteksskrywer, ten einde te vermy dat die gedig disintegreer in wat hy noem "arbitrarily cut-up prose" (1975:61). Twee maniere waarop dit gedoen kan word, is die gebruik van weglating en die aksentuering van sillabes wat nie normaalweg klem dra nie (Lefevere 1975:62-67). Interjeksies en byvoegings kan ook benut word, sowel as toutologie en herhaling, met vaste uitdrukkings en parafrasering as laaste uitweg. Uitbreiding en sametrekking is volgens Lefevere die hoofmiddele wat in die vryeversmodus aangewend word (Lefevere 1975:70). Assimilasie, assonansie, interne rym en enjambement kan verder die eentonigheid van wat Lefevere noem die "beat of the metrical scheme" verlig (1975:72). Laastens kan metaforiese taalgebruik en die plasing van woorde in die versreël op 'n plek waar hulle nie normaalweg hoort nie, ook die nodige effek bewerkstellig (Lefevere 1975:73-75). Lefevere is van mening dat vryeversvertaling bes moontlik die beste produk tot gevolg het uit die ses genoemde benaderings, hoewel dit ook tekortkominge het $(1975: 76)$.

Dit is dan ook opmerklik dat Cussons kwistig van 'n soort vryeversvertaalmodus gebruik maak deur in heelparty gevalle reëls weg te laat of in te voeg in die vertaalde gedig. Die eerste verklaring hiervoor is waarskynlik die feit dat haar gedigte in die bundel in die eerste plek in die vryeversvorm geskryf is en daar dus met redelike sekerheid vermoed kan word dat 'n vryeversvertaling die verkose vorm sal wees. Uit haar vertalings wat van hierdie strategie gebruik maak, is dit duidelik dat daar 'n soort kreatiewe herverbeelding van bepaalde versreëls plaasgevind het wat gelei het tot hulle verskuiwing, skrapping, verdeling of aanpassing. In die geval van 11 uit die 37 gedigte verander sy byvoorbeeld die aantal reëls deur skrappings of byvoegings, of verander sy die volgorde van versreëls in die vertaling. Die veranderings is egter besonder gering - die meeste wat uit 'n gedig weggehaal word, is een reël, en dis ook die maksimale toevoeging. Vergelyk byvoorbeeld die tweede strofe van "Japanese painting on silk" (15) met sy Afrikaanse bronteks, of die Engelse "A slice of bread" (51) met "n Sny brood" (50). 'n Hebbelikheid wat verder onder hierdie hofie bespreek kan word, is die feit dat sy in meer as die helfte van die gedigte minstens een keer die werkwoord aan die einde van 'n versreël vervang met ' $n$ ander woordsoort en ongeveer ewe gereeld 'n werkwoord aan die einde van die Engelse reël sit waar dit nie in Afrikaans daar gestaan het nie - 'n aanduiding dat sy haar in Engels deur die idiomatiese Engelse sinspatroon laat lei en nie die Afrikaanse patroon probeer behou nie. Twee voorbeelde ter illustrasie van die bogenoemde:

Ek het vergeet wat ons gesê het, lief, die tyd het oud geword en ek lê eenkant en niemand praat daar's niemand nie - het stil geword. Kind in my wat nooit sal ken nie nooit en nooit nie - stief grootgeword ...

Hóé om die soet wanneer brood en spoeg mekaar herken presies te definieer:
I have forgotten what we said, love, the time has long been oldand I lie apart, no-one speaks there's nobody - has long been still. Child who will never know me, never and never - grown up orphaned.

(Cussons 1985:20-21)

How to define

the sweetness when bread and spittle recognise each other- 
U liggaam is legio en subtiel maar al my denkende smaaktepels weet: as net die woord gevind kan word, maak elke duister en tergende en verwikkelde ding meteens verbasend sin.
Your Body is legion and subtlebut all my reflective taste buds know: if only the word could be found then every obscure and vexing and difficult thing would suddenly make amazing sense.

(Cussons 1985:50-51).

Lefevere se laaste strategie is die een wat hy interpretasie noem en wat onderverdeel word in "versions" en "imitations", oftewel, weergawes en nabootsings, en ook apart gesien word van gewone vertalings (Lefevere 1975:76). Die "weergawe" is 'n teks waarin oënskynlik groter kommunikatiewe waarde as in die bronteks voorkom, spreektaal ingesluit word, bykomende vergelykings en addisionele metafore ingebring word, die leser soms deur die vertaler aangespreek word, en kommentaar by geleentheid deur die vertaler gelewer word, alles met die implikasie dat dit wat implisiet in die bronteks voorkom (of geïnterpreteer word as so synde) meer eksplisiet genoem word in die vertaling (Lefevere 1975:76-82). 'n Nabootsing, soos die naam dit stel, kom basies neer op 'n (hoofsaaklik vormlike) nabootsing van die bronteks, met oorvleueling wat plek-plek voorkom. Dié nabootsing kan selfs 'n totaal ander interpretasie van die semantiese/feitelike gegewens van die bronteks behels (Lefevere 1975:84). Ook hier kom 'n eggo voor van 'n ander vertaler, naamlik Ezra Pound, met die volgende stelling: "The translation of a poem having any depth ends by being one of two things: Either it is the expression of the translator, virtually a new poem, or it is as it were a photograph, as exact as possible, of one side of the statue" (in Venuti 2008:164).

Cussons se vertalings kan nie werklik as "weergawes" beskryf word nie, omdat hulle vormlik uiters naby die bronteks hou en nie werklik ekspliserend aandoen nie. Dit sou gestel kon word dat haar gedigte in hierdie strategie se terme eerder na die kant van nabootsings neig, aangesien daar besonder duidelike vormlike en inhoudelike ooreenkoms in elke enkele gedig in die bundel voorkom, hoewel daar tog nie sprake is van wat Lefevere beskryf as 'n nuwe of ander interpretasie van die aangebode inligting in die bronteks nie.

Dit blyk dus dat Cussons se vertalings nie noodwendig blyke van al die strategieë gee wat Lefevere as moontlikhede verskaf nie. Lefevere se klankvertaling, metriese vertaling, prosavertalings en interpretasies kom nie in die bundel voor nie (in sekere gevalle kom selfs die teenoorgestelde van 'n bepaalde strategie voor, byvoorbeeld in die geval waar metrum verlore gaan ter wille van semantiese inhoud), terwyl daar van letterlike vertaling en rymende vertaling tog enkele voorbeelde voorkom. Van die vryeversmodus word daar wel algemeen gebruik gemaak, hoewel dit, soos hierbo genoem, waarskynlik ten dele die gevolg is daarvan dat heelparty van die Afrikaanse gedigte oorspronklik in dié vorm geskryf is.

In Lefevere se model word nie werklik omvattend voorsiening gemaak vir gedigte wat, soos in Cussons se geval, sowel vormlik as inhoudelik baie naby die brontekste bly nie. Nietemin is daar, soos aangetoon, ook nut aan Lefevere se indeling, veral vir die klassifikasie van dit wat wel verander in die vertalings. Cussons se vertalings is egter deurgaans baie soortgelyk aan haar brontekste, soms selfs tot op die tipografiese vlak, wat kan verklaar waarom heelparty van Lefevere se strategieë nie voorkom nie. 


\subsection{Benutting van ander strategieë}

In Cussons se vertaling sit ook blyke van tendense wat nie spesifiek onder Lefevere se strategieë ingedeel kan word nie. In hierdie afdeling word 'n seleksie uit hierdie tendense gemaak en word 'n voorstel ter oplossing ook gemaak. Voorts dan die hebbelikhede wat uit die bundel blyk.

In die geval van die besitsvorm is dit opmerklik dat Cussons nêrens die apostroof in Engels gebruik nie, maar deurgaans kies vir die "of"-vorm, byvoorbeeld by "God se vingertop" (14) teenoor "the finger-tip of God" (15).

By woorde wat goddelike of religieuse verwysings inhou, spesifiek die naamwoordelike vorme, is daar ook nie 'n duidelike strategie van hoofletter- teenoor kleinlettergebruik in die vertalings nie. Dit kom voor asof Cussons gewoon idiosinkraties te werk gegaan het - op party plekke word "heer" (40) in Engels "Lord" (41) en "liggaam" (50) eweneens "Body" (51). By nadere ondersoek blyk dit egter dat die hoofletters in die Afrikaans deurgaans ook na Engels oorgedra is, plus addisionele hoofletters wat bygevoeg is in die Engelse gedigte. Moontlik is dit weer 'n Engelse konvensie wat hier kop uitsteek eerder as 'n bepaalde definitiewe poëtiese of vertaalmatige besluit, maar dit is nietemin opvallend.

Vier van die gedigte se titels word vormlik aangepas: "Klein ballade" verander in "Ballad" (2829), "Corpus Christi" in "Eve of Corpus Christi" (30-31), "Die krusifiks" in "Crucifix" (74-75) en laastens "Taal van die kospot" in "My cooking-pot" (78-79).

In enkele gevalle word ook betekenis bygeskryf, byvoorbeeld "trappel" (58) wat vertaal is as "race my little feet" (59), en in ander gevalle is daar 'n mate van betekenisverskuiwing: "verbaas" (58) word "exhilarated" (59), "my bloed" en "vernietig" (26) word onderskeidelik "myself" en "rend" (27), en "gees" (40) word "mind" (41).

Laastens word woorde of frases wat verwys na lig en vuur, 'n tematies-belangrike element in Cussons se werk (vergelyk byvoorbeeld Viljoen 2008:277 en Janse van Rensburg 2012:281, 285-287), aangebied. Dit blyk duidelik uit die lys hier onder dat dieselfde woord nie in elke geval dieselfde vertaal word nie (vergelyk byvoorbeeld "blink") en dat daar ook nie konsekwent te werk gegaan word by byvoorbeeld hooflettergebruik nie (vergelyk "Gloed"). Uit die lees van die gedigte waarin die betrokke woorde voorkom, is dit ook nie moontlik om oortuigend aan te toon dat daar by hierdie tematies-belangrike verwysingswoorde 'n opsigtelike of aantoonbare strategie gevolg word nie. Dit kom gewoon voor asof die digter idiosinkraties te werk gegaan het op grond van haar herverbeelding van die Afrikaanse teks wanneer sy die Engelse teks geskep het eerder as om 'n vaste strategie te volg.

Afrikaans
blink
blink
blink
blink te blink
blink-onmiddellik
blink-oog
blond in die heilige lig
deurgloei
deursigtig soos 'n vlam
deurskynend

\author{
Engels \\ bright \\ shining \\ brightly \\ shines too shiningly \\ brightly immediate \\ bright-eyed \\ blonde in the holy light \\ irradiated \\ transparent as a flame \\ incandescent
}




die ene lig
donker
donker
duister
flikkergebare
flits
flits
glans
glinster
glinsterende
glinstervliegie
(die) Gloed
Gloed
gloeiende
harde hemel
helder
in volle gloed
natblink
oggendsonlig
ondersese lig
ontplof
prag van vuur
sengende
siende weelde
skaduwee
skitter
skyn
so helder soos 'n geseënde gemoed
Son-Hy
vlam
vlammende
vurige hakskeen

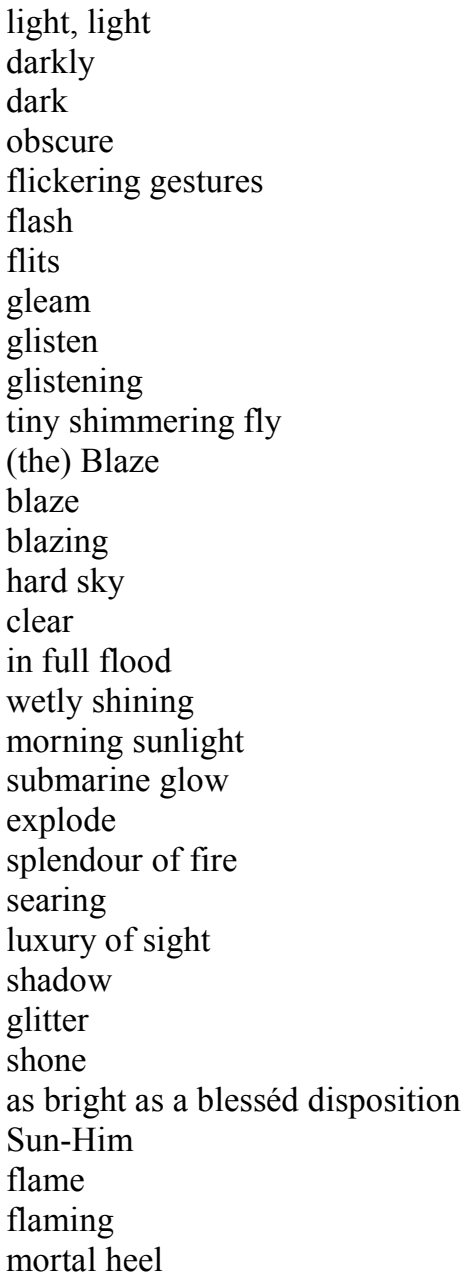

Cussons se strategieë wat nie spesifiek onder Lefevere s'n inpas nie, sluit dus in die benutting van die "of"-vorm eerder as die apostroof om die besitsvorm in Engels te skryf, die vormlike aanpassing van gedigtitels en die skynbaar idiosinkratiese hantering van tematies-belangrike woorde.

In Lefevere se model is daar nie 'n presiese verklaring vir hierdie soort handelinge of 'n strategie waaronder hulle ingedeel kan word nie, buiten om die gedigte waarin hulle voorkom, breedweg te klassifiseer as "weergawes".

Die voorstel is dat op grond van die bogenoemde 'n meer mikrotekstuele of taalgeoriënteerde strategie by poësievertaling nodig is. Om enigsins volledigheid in die deskriptiewe ondersoek na vertaalde poësie te probeer behaal, is dit nodig dat Lefevere se model, hoewel nuttig uit 'n literêr-kritiese oogpunt, miskien op teks- en taalvlak aangevul moet word om vertaalkeuses op die mikrovlak bevredigend te verklaar in gedigte waar daar groot vormlike en inhoudelike ooreenstemming, maar ook heelwat fyn talige verskeidenheid of selfs afwykings voorkom.

\subsection{Die gedig wat oënskynlik Cussons se eie vertaalreëls oortree}

Die vertaalde gedigte wat in die bostaande twee afdelings ondersoek is, het deurgaans vormlik en inhoudelik besonder sterk ooreengestem met hul brontekste. 'n Gedig wat 'n eie afdeling in hierdie ondersoek verdien omdat dit nié hierdie ooreenstemming toon nie, is die Engelse 
vertaling van "Christ of the burnt men" (Cussons 1985:32-33). Hierdie gedig is sekerlik Cussons se mees-bestudeerde en haar sentrale religieuse vers (Hambidge 2004). In komende werk oor selfvertaling teenoor ander-vertaling word die ingrypende aanpassings wat hier aangebring is, in nadere besonderhede bestudeer, maar in kort sou dit beskryf kon word as 'n gedig wat nie net vertaal is nie, maar totaal herverbeel en ingrypend aangepas word. Ter illustrasie van hoe selfs in 'n bundel vol gedigvertalings wat vormlik en inhoudelik besonder sterk ooreenstem, tog ook 'n gedig staan wat voldoen aan geen van die reëls of riglyne waarvolgens Cussons skynbaar die res van die vertalings gemaak het nie:

\section{"Christ of the burnt men" \\ Thomas Merton}

Jy sal my ook al hoe meer wen, glimlaggende skerts-oog blink-oog Christus wat my vervaarde jare op jou afstand gadegeslaan het: jy het jou hande nie tóé uitgesteek toe ek jou sengende wonde aan my lyf ontvang het nie maar fel jou kruis geteken oor my, in hand en voet en romp en hoof, en deur die beswyming onder druppende bloedplasma- en soutwatersakke kom skyn voor my met net die trekking van 'n glimlag van uiterste pyn om die mondhoeke, jou oë blink van 'n verskriklike akkoord.

En ek begryp, jy het my geteken vir die avontuur van jóú, ek wat vuur bemin en altyd waaghalsig was - $\mathrm{O}$ wat is die brand in brein en hart wat brandender brand as die vlam aan die lyf en wat gaan gloei in klip en sand onder my eenvoetig-springende begrip agter jou ságsinnigheid aan?: Nee, iets is heerlikers: as jy eindelik omdraai met oë wit en stip en ver en skouers gemantel met ' $n$ verwoede en stormende son: o my kosmiese Christus: drie-en-dertig jaar verdoesel in die klein en donker vlees wat jy in een nag oopgevlek het om jóu vir my te bevry opdat ek jou raak sien, raak weet, raak het, en nog wag jy dat ek moet sê, heeluit moet sê: grýp my hande dan, amper sonder vingers vir jou: kundige timmerman.

\section{"Christ of the burnt men" \\ Thomas Merton}

I suppose you'll have me wholly, yet, smiling, jest-eyed, bright-eyed Christ who regarded my headlong years from your distance: You didn't reach out your hands even then when I received your searing wounds in my body, but under the dripping bloodplasm and salt water bags came and shone me back into consciousness grinning, like a brother, to mitigate your terrible eyes O Thou - it was you allowed it - how else? - you marking me for the adventure of You, freeing me, Fire in fire, from all that womb and world had embedded me in And still you wait, until I say, say wholeheartedly: Seize my hands then, almost fingerless for you, Ingenious Artisan. 
Dit is 'n vertaling waarin 'n groot gedeelte van die persoonlike gesprek wat die spreker met die goddelike entiteit voer, in die vertaling uitgelaat is. Hierdie weglating veroorsaak 'n ingrypende verandering aan die toon van die gedig, asook nuttige stof vir die verdere pogings om vertaalstrategieë te probeer agterhaal deur middel van 'n bestudering van vertaalde gedigte langs hul Afrikaanse brontekste. Die reëls word anders verdeel, klem word verskuif, metrum word aangepas en sekere beelde word geëkspliseer, of minstens in meer besonderhede beskryf as in die Afrikaanse bronteks. Uiteindelik is hierdie Engelse vertaling van die ikoniese Afrikaanse vers myns insiens glad nie 'n ongeslaagde of verswakte vers nie; die poësie het hier allermins verlore gegaan.

Gedagtig aan Lefevere se strategieë sou hierdie gedig waarskynlik beskryf kon word as iets tussen 'n "weergawe" en 'n prosavertaling. Ook hier is Lefevere se model, hoewel origens nuttig, egter nie volledig genoeg om alles te verklaar wat in die vertaling voorkom of bygevoeg of weggelaat is nie. Ook hier word die behoefte aan 'n meer taalgeoriënteerde instrument ondervind.

\section{Gevolgtrekkings}

Is daar dus by Cussons 'n "tipiese" vertaalstrategie? Dit sou gestel kon word dat sy met die uitsondering van een voorbeeld deurgaans 'n soort vertaalde gedig maak wat vormlik, inhoudelik en spesifiek semanties besonder sterk ooreenstem met die betrokke bronteks. Dit blyk duidelik deur te kyk na byvoorbeeld die gedig "Vraag" en sy Engelse vertaling "Query", waar die ooreenstemming selfs op tipografiese vlak opsigtelik is:

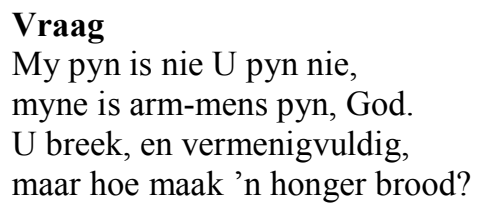

\author{
Query \\ My pain is not your pain, \\ mine is pauper-pain, God. \\ You break and multiply \\ but what does a hungry bread do?
}

(Cussons 1985:16-17)

Hierdie soort sterk ooreenstemming en die afgeleide strategie vind egter moeilik staanplek in Lefevere se indeling. Dit sou beskryf kon word as nabootsend van aard, aangesien elemente daarvan breedweg ooreenstem tussen die weergawes, maar gedagtig aan Lefevere se beskrywing dat 'n nabootsing eintlik 'n afsonderlike gedig is wat eintlik net die titel en basiese idee van die gedig gemeen het met die bronteks (1975:76), blyk dit dat dit ook nie 'n geskikte verklaring is nie.

Eweneens is daar heelwat gevalle, soos aangetoon, waar Cussons se vertalings blyke gee van addisionele handelinge of besluite wat ook nie volledig deur een of meer van Lefevere se sewe strategieë ondervang word nie. Dit kom verder voor asof Lefevere se strategieë deurgaans beskrywings bevat van meer ingrypende wysigings as wat op enige punt uit Cussons se vertalings blyk, met die moontlike uitsondering van "Christ of the burnt men" waar dramaties verkort en verander is, soos aangetoon. Dit kan wel gestel word dat Cussons se vertalings voldoen aan Lefevere se beskrywing waarvolgens die vertaler 'n vertaling moet maak wat op die oorkoepelende vlak getrou is aan die oorspronklike, terwyl fyner detail nie 'n struikelblok word nie (Lefevere 1975:103); daar sou veronderstel kon word dat dit relatief maklik is vir die vertaler om die skrywer se "padkaart", soos Lefevere (ibid.) dit noem, te volg as die vertaler 
self daardie skrywer is. Die vertalings is semanties en vormlik in sterk ooreenstemming met die brontekste, en die hebbelikhede wat in 4.2 bespreek is, is nie so opvallend dat dit die leser behoort te steur nie. Lefevere se strategieë bied egter nie die moontlikheid om die presiese wyse waarop daar by hierdie vertalings uitgekom word, te beskryf nie, en derhalwe is dit vir die ondersoeker in deskriptiewe terme minder waardevol as wat 'n boek wat as "bloudruk" bestempel word, na verwagting sou wees.

Uit die bogenoemde blyk dit dus dat hoewel Lefevere ' $n$ voorloper in die meer sistematiese beskrywing van poësievertaling is, daar bepaalde tekortkominge aan sy indeling is wat blyk uit 'n praktiese bestudering van Engelse vertalings van Afrikaanse gedigte. Sekere vertaalstrategieë word goed verklaar, byvoorbeeld die gebruik van vryeversvertaling en van interpreterende vertaling (weergawes eerder as nabootsings, soos aangetoon) terwyl ander, soos hooflettergebruik al dan nie, mikrotekstuele wysigings en inkonsekwentheid, nie so goed verklaar word nie.

Lefevere self spreek hom sterk uit teen die ontleding van vertalings uit 'n suiwer linguistiese oogpunt, aangesien die ondersoeker volgens hom dan neig om eensydig vas te haak by die linguistiese aspekte van literatuur en, derhalwe, slegs die linguistiese aspekte van die vertaalproses (1975:3).

My indruk is dat ' $n$ meer taalgeoriënteerde benadering in kombinasie met Lefevere se aanvanklike strategieë tog van groter nut kan wees in die deskriptiewe ondersoek na poësievertaling uit Afrikaans in Engels as enige van die twee op hul eie. Hierdie hipotese word in 'n verdere ondersoek uitgebrei.

\section{Bronnelys}

Bassnett, S. 1998. Transplanting the seed: Poetry and translation. In S. Bassnett en A. Levefere (reds.). Constructing cultures: Essays on literary translation. Clevedon: Multilingual matters. pp. 57-75.

Boase-Beier, J. 2009. Poetry. In M. Baker en G. Saldanha (reds.). Routledge encyclopedia of translation studies. (2de uitgawe). New York/Londen: Routledge. pp. 194-196.

Benjamin, W. 1923. "The task of the translator: An introduction to the translation of Baudelaire's Tableaux Parisiens". In L. Venuti (red.). The translation studies reader. (2de uitgawe). Londen/New York: Routledge. pp. 75-85.

Borges, J.L. 1981. Die vorm van die swaard en ander verhale (vert. Sheila Cussons). Kaapstad: Tafelberg.

Connolly, D. 2001. Poetry translation. In M. Baker (red.). Routledge encyclopedia of translation studies. New York/Londen: Routledge. pp. 170-176.

Cussons, S. 1985. Poems: a selection. Kaapstad: Tafelberg. 
De Villiers, D.W. 1982. Vuur by Sheila Cussons. Ongepubliseerde magistertesis. Stellenbosch: Universiteit Stellenbosch.

De Villiers, J.H. 1984. Engel en aarde: Gedagtes oor "natuur en bo natuur" by die lees van Sheila Cussons. Ongepubliseerde magistertesis. Grahamstad: Rhodes-universiteit.

Engelbrecht, G.C. 2012. Bybelse intertekste in resente Afrikaanse gedigte en lirieke, met spesifieke verwysing na identiteitsformasies in die (post)-postmoderniteit. Ongepubliseerde $\mathrm{PhD}$-proefskrif. Stellenbosch: Universiteit Stellenbosch.

Feinstein, S. 2005. Sunshine, blossoms and blood: H.N. Bialik in his time, a literary biography. Lanham: University Press of America.

Fochi, A. 2011. The issue of rhythm, metre, rhyme in poet-translators - Ungaretti, Montale and Shakespeare's Sonnets in Intralinea (13). [Internet]. Beskikbaar: http://www.intralinea.org/ archive/article/The Issue of Rhythm_Metre_Rhyme in Poet-Translators

Gilfillan, F.R. 1984. Geel grammofoon. Perspektiewe op die werk van Sheila Cussons. Kaapstad: Tafelberg.

Hambidge, J. 2004. Sheila Cussons. [Internet]. Beskikbaar: http://www.oulitnet.co.za/poesie/ sheila_cussons.asp (13 Januarie 2014).

Hambidge, J. 2013. Sheila Cussons - Versamelde gedigte (2006). [Internet]. Beskikbaar: http://joanhambidge.blogspot.com/2013/02/sheila-cussons-versamelde-gedigte-2006.html. (27 November 2014).

Hermans, T. (red.) 1985. The manipulation of literature. Studies in literary translation. New York: St Martin's Press.

Janse van Rensburg, C. 1995. Die eksplisiete versinterne poëtika van Sheila Cussons: 'n ondersoek na haar metapoësie. Ongepubliseerde magistertesis. Stellenbosch: Universiteit Stellenbosch.

Janse van Rensburg, C. 2012. Die mistieke dimensie en kontemplatiewe aard van die kreatiewe daad by Sheila Cussons. LitNet Akademies 9(1), Maart: 273-300.

Jones, F.R. 2011. Poetry translating as expert action: processes, priorities and networks. Amsterdam: John Benjamins.

Kannemeyer, J.C. 2005. Die Afrikaanse literatuur 1652-2004. Kaapstad: Human \& Rousseau.

Kelly, N. en Zetzsche, J. 2012. Found in translation. How language shapes our lives and transforms the world. Perigee: New York.

Kenesei, A. 2010. Poetry translation through reception and cognition. The proof of translation is in the reading. Newcastle upon Tyne: Cambridge Scholars Publishing. 
Lefevere, A. 1975. Translating poetry: Seven strategies and a blueprint. Amsterdam: Van Gorcum.

Levý, J. 1963. Umeni prekladu. Praag: Československý spisovatel.

Levý, J. 2011. The art of translation (vert. Zuzana Jettmarova). Amsterdam: John Benjamins.

Malan, M. 2013. Wêreld kan nou Afrikaanse poësie lees. [Internet]. Beskikbaar: http://www.rapport.co.za/Boeke/Nuus/Wereld-kan-nou-Afrikaanse-poesie-lees-20130705. (16 Januarie 2014).

Matthee, M. 1984. Godsdienstige perspektiewe in Die woedende brood en Verwikkelde lyn van Sheila Cussons. Ongepubliseerde magistertesis. Bloemfontein: Universiteit van die OranjeVrystaat.

Munday, J. 2008. Introducing translation studies. Theories and applications. (2de uitgawe). Londen/New York: Routledge.

Nabokov, V. 1955. Problems of translation: Onegin in English. In L. Venuti (red.). The translation studies reader. (2de uitgawe). Londen/New York: Routledge. pp. 115-127.

Raffel, B. 1988. The art of translating poetry. University Park: Pennsylvania State University Press.

Robinson, P. 2010. Poetry \& translation: The art of the impossible. Liverpool: Liverpool University Press.

Scholtz, A. 1991. Skepper en skepping: Die visuele as essensiële element in die poësie van Sheila Cussons. Ongepubliseerde magistertesis. Stellenbosch: Universiteit Stellenbosch.

Steiner, G. 1975. After Babel. Aspects of language and translation. (3de uitgawe). Oxford: Oxford University Press.

Swart, M. 2009. Twee Afrikaanse romans in Engels. 'n Ondersoek na die werkswyses van literêre vertalers. Ongepubliseerde magistertesis. Stellenbosch: Universiteit Stellenbosch.

Toury, G. 1995. Descriptive translation studies and beyond. Amsterdam: John Benjamins.

Van den Berg, C. 2006. Engelse teks verhoog waardering vir oorspronklike. Volksblad, 13 Februarie, 8 .

Van Vuuren, H.E. 1989. St. Teresa van Avila: Sentrale figuur in die werk van Cussons en Van Wyk Louw. Literator 10(3): 85-97.

Venuti, L. 2008. The translator's invisibility. A history of translation. (2de uitgawe). Londen: Routledge.

Viljoen, L. 2007. Digterlike gesprekke met Van Wyk Louw. Tydskrif vir Geesteswetenskappe 48(3): 267-291. 